\section{Canada's nuclear fallout}

Published at www.cmaj.ca on Feb. 4, 2008. Revised Feb. 6.

$\mathrm{T}$ his may come as a surprise, but the Ontario town of Chalk River was once mentioned in sentences that didn't contain the word "fiasco." Anyone who's glanced at a newspaper in the past 3 months knows those days are over.

The ongoing controversy over the December closure of the Chalk River nuclear reactor, which produces the raw materials for half the world's medical isotopes, has become an international embarrassment for Canada. Now, some European isotope producers claim Ottawa-based MDS Nordion, the dominant player in nuclear medicine, has brought its recent troubles upon itself by refusing to take part in efforts to coordinate the global isotope supply. Meanwhile, animosity in the United States toward MDS Nordion over the recent shortage is prompting calls for the creation of a domestic supplier, which would rob the company of its biggest customer.
Although the health care implications of the Chalk River kerfuffle are serious, the many headlines declaring a worldwide isotope shortage may have been premature, if not errant. Countries like Canada, the United States and Japan were facing shortages that would have resulted in thousands of cancelled diagnostic and therapeutic procedures, but it was business as usual for European nuclear medicine practitioners.

Europe's 2 large-scale isotope suppliers - the Nuclear Research and Consultancy Group in the Netherlands and the Institut National des Radioéléments in Belgium - coordinate their production schedules to ensure I reactor is always running. They also have open communication with Nuclear Technology Products in South Africa. Some in the international nuclear medicine community claim that foreign producers could have buoyed the North American supply chain, had Canada been a better global partner.

"The one problem we have is that we never get information from the Canadians," says Kevin Charlton, commercial manager for business develop-

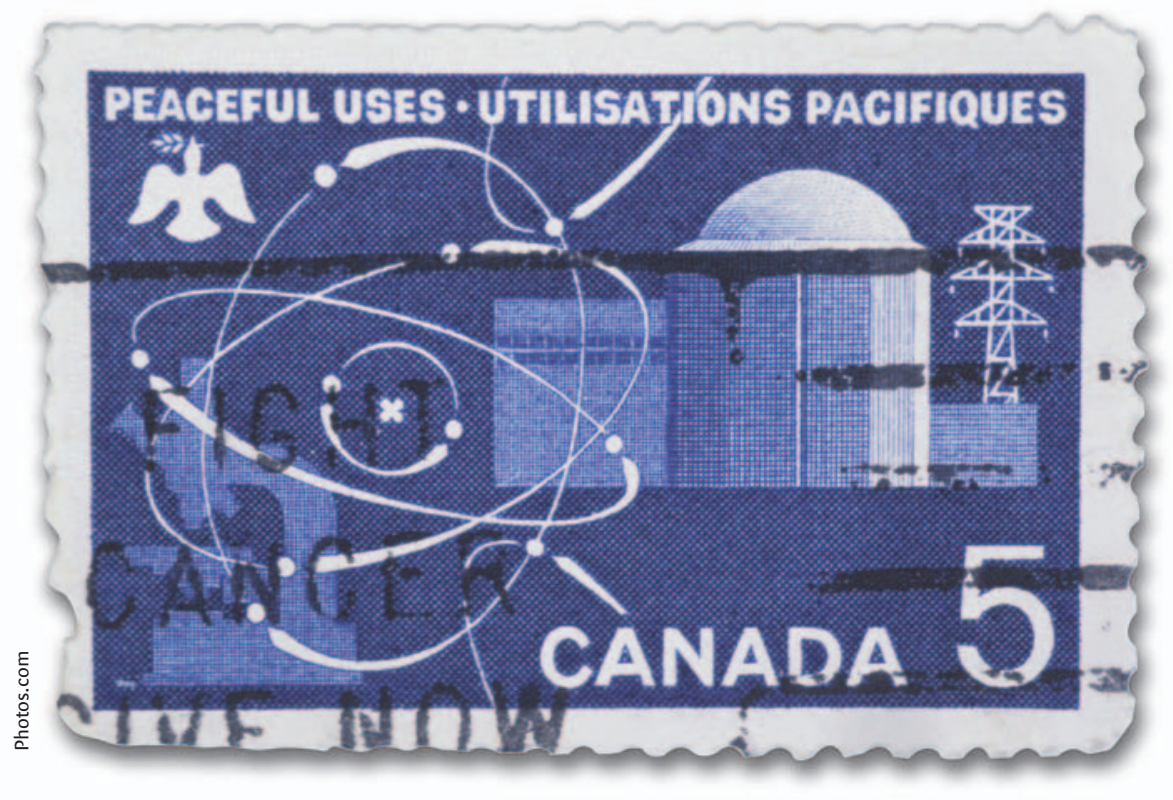

The National Research Universal reactor went critical on Nov. 3, 1957. It was built to supply medical isotopes, serve as a site for neutron physics research and provide developmental support for CANDU power reactors. ment and sales with the Nuclear Research and Consultancy Group.

Canadian Society of Nuclear Medicine President Dr. Jean-Luc Urbain claims foreign isotope producers were not capable of picking up the slack. But others, like University of Texas public affairs professor Alan J. Kuperman, argue MDS Nordion has no interest in international contingency planning. "They see themselves as the big dog. They are not going to share information with the small ones nipping at their heels."

"There is all sorts of surplus capacity," says Kuperman. "Nordion and AECL [Atomic Energy of Canada Ltd.] obviously knew there was an option of going to other suppliers.... Instead, they went to the public and the Canadian government. That was misleading and, one could argue, socially irresponsible."

Kuperman says MDS Nordion has a history of using scare tactics to bully the United States, which is dependent upon the company to meet its nuclear medicine needs. He also claims the company broke its promise to convert its facilities to use low-enriched instead of bomb-grade uranium. The recent shortage scare may have provided the final push the United States government needed to establish a domestic isotope producer.

"Nordion thumbed its nose at the US government. They couldn't be happier if Nordion gets its comeuppance."

Most of the media coverage of the Chalk River shutdown has focused on the usual political scapegoating. But some questions remain: Why is something as important as the world's medical isotope supply so dependent on a half-century-old reactor? Will coordination with Europe be improved to guard against future shortages? How long will it be before the United States starts making its own isotopes?

Whatever the answers to those queries, there is a fallout from the Chalk River mess that many nuclear experts believe is beyond question: Canada's days as top dog in the medical isotope game may be numbered.

Although better known as the dough- 
nut capital of the world, Canada has long been admired for its contribution to nuclear medicine. The global nuclear imaging and therapeutics market is estimated at $\$ 3.7$ billion. MDS Nordion says its share is less than $\$ 290$ million.

The company, a subsidiary of Toronto-based health care giant MDS Inc., has a licensing agreement with Atomic Energy of Canada Ltd., the Crown corporation that owns the Chalk River reactor (Box I). MDS Nordion turns raw materials from the 50year-old reactor into medical isotopes used to diagnose ailments such as cancer and heart disease and to treat conditions like non-Hodgkin's lymphoma.

The workhorse of nuclear medicine, used in more than $80 \%$ of imaging studies, is technetium-99. It derives from a parent isotope, molybdenum-99, of which MDS Nordion makes more than half the global supply. In December, that supply seemed to be in jeopardy.

On Dec. 4, Atomic Energy of Canada Ltd. extended a 5-day shutdown of the reactor, which had been undergoing routine maintenance, to install a safety feature. Doctors across North America decried the closure, claiming it would mean cancelling thousands of diagnostic and therapeutic procedures. Their cries didn't fall on deaf ears; less than 2 weeks later, the federal government fast-tracked a bill to reopen the reactor.

Of course, all this fuss would have been avoided if MDS Nordion had brought 2 new reactors online by 2000 , as it had proposed. The company began building the reactors, the only ones in the world designed exclusively to produce medical isotopes, in the midI990s, pegging their cost at \$I40 million. Instead, MDS Nordion poured nearly $\$ 350$ million into the project.

Atomic Energy of Canada Ltd. took over the project in 2006, paying MDS Nordion $\$ 25$ million for its facilities and $\$ 53$ million for inventory. But due to continuing technical problems, the reactors, though completed, remain idle.

Dr. Sandy McEwan, president of the Virginia-based Society of Nuclear Medicine, believes other countries avoided investing in isotope production because they expected the new reactors to secure the global supply. Considering

\section{Box 1: Nuclear power and research reactors}

All nuclear reactors split atoms of various elements to essentially produce and release energy. But those that produce power differ in many ways from those used to make radioisotopes.

- A power reactor is designed to generate heat, which, in turn, is used to generate steam to power electricity-producing turbines. They are sometimes referred to as high-temperature, high-pressure reactors. Facilities housing power reactors require complicated cooling systems.

- Research reactors are simpler in design, use much less fuel, generate far less heat and have smaller cores. They utilize the actual neutrons produced in the core.

- The National Research Universal reactor runs at 135 MW using low-enriched uranium fuel. By comparison, current CANDU power reactors can generate as much as $1200 \mathrm{MW}$.

the many other deterrents to entering the industry - the scarcity of nuclear technology experts, high infrastructure costs, the challenge of distributing decaying-by-the-minute radioactive material - it's little surprise isotope suppliers form an exclusive club.

"The world is dependent on a small number of reactors creating this stuff," says McEwan.

Furthermore, the trend in recent years has been to close reactors, not open them. The number of isotopeproducing reactors in the world has been steadily decreasing for some time. This is disconcerting, as the existing reactors are getting old. The Netherlands' reactor is more than 40 years old, as is South Africa's.

Still, there is little concern about an isotope shortage in Europe because the suppliers set aside their commercial interests and discuss common problems in safety, distribution and legislation. More importantly, they schedule their outages so they don't coincide. But MDS Nordion, it seems, is reluctant to reveal details about its operations.

"Nordion is represented at our meetings," says Charlton. "Either AECL doesn't tell Nordion or they don't allow Nordion to tell us."

In reaction to the recent shortage, a European economic interest group called the Association of Imaging Producers and Equipment Suppliers is calling for the creation of a global coordination policy. On Dec. I4, it issued a press release stating that "a broader consultation between all stakeholders has to take place to ensure sufficient supplies in the future."
"We need to improve communication between North America and Europe," says Guy Turquet de Beauregard, the association's vice president.

Atomic Energy of Canada Ltd. says that's MDS Nordion's responsibilty. "It's not for us to comment on the global marketplace for isotopes," says Dale Coffin, director of corporate communications. "Our commercial obligations are to MDS Nordion. We aren't in the supply chain part of the business."

MDS Nordion, meanwhile, states it did try to coordinate alternative sources of supply, after the shutdown was ordered. "Given that the extended shutdown of AECL's NRU reactor was a precipitous event, any type of advanced international schedule collaboration would not have mitigated this unplanned event," the company states in a response to the Feb. 4, 2008, electronic version of this article.

Urbain says Canada has been a good global team player. "In Europe, they probably see this as a wonderful opportunity. Someone's misfortune can make somebody else a fortune."

Beauregard says his association isn't powerful enough to compel MDS Nordion to share information, but he hopes that concern for the millions of patients who depend on their products will.

If so, European producers would be better prepared to supply isotopes to North America if future problems arise. He also hopes to see the new Canadian reactors operating soon.

"In Europe we are disappointed we don't see the reactors running. We asked Nordion why that is, but we only see the fact that the reactors aren't working." 
MDS Nordion's reputation in the United States is no less sullied. Americans depend upon Canada for more than hockey players and maple syrup. There are some I2 million nuclear medicine procedures performed annually in that country, which has no domestic supplier. And demand is rising by $10 \%$ each year. The vast majority of its isotopes are purchased from MDS Nordion - for now.

Robert Schenter, the chief science officer of Washington-based Advanced Medical Isotope Corporation, says many American nuclear scientists are urging their government to develop a domestic source. The Chalk River woes have only made those voices louder. "With the Canadians not coming through, with the baby boomers getting older and with more publicity on using nuclear medicine, it's more likely that a domestic source will be created," he says. "I think the other issue is that the dumb doctors just assumed they would get their isotopes and it took a good knock on the head to get them concerned about their supply."

The most likely production facility is the University of Missouri-Columbia's reactor. Although it's a high-powered university research reactor, it would take 3 or 4 years' work to ready it for largescale production. In the meantime, says Schenter, MDS Nordion would be wise to diversify its product line - a sharp decline in its American molybdenum-99 sales is inevitable.

American doctors have long been MDS Nordion's greatest allies south of the border. The company certainly doesn't need more enemies, as it already has a formidable foe in the nonproliferation movement. Americans concerned about nuclear safety have for years scolded the US government for sending bomb-grade uranium to Canada to make isotopes.

For fear of it falling into terrorists' hands, the United States began phasing out exports of highly enriched uranium in the late I970s. The Energy Policy Act of 1992 included incentives for foreign uranium buyers if they promised to convert to technology that used lowenriched uranium, which isn't bombgrade. According to Kuperman, who is also a policy analyst for the Nuclear Control Institute, MDS Nordion made that promise - then broke it.

Not only that, he says, MDS Nordion pressured the US government to relax its stance on uranium exports. The company warned restrictions might interrupt the isotope supply. Then, nuclear lobbyists leaned on North Carolina Congressman Richard Burr to amend the energy bill to waive restrictions on exporting bombgrade uranium to 5 countries, including Canada, Belgium and the Netherlands.

The lobbyists, who Kuperman claims made substantial contributions to the congressman's previous campaign, succeeded. President George W. Bush signed the bill, amendment included, on Aug. 8, 2005. "It is a cautionary tale of how a single foreign company can weaken US national security through misleading scare tactics and cold cash," Kuperman wrote in the Bulletin of the Atomic Scientists.

Now, with physicians joining the cause, he says there is no doubt a domestic isotope supplier will be established in the near future. And there will be few tears shed south of the border if MDS Nordion's bottom line takes a beating.

"These folks have used up all their goodwill. It's gone. There is no one feeling sorry for Nordion." - Roger Collier, $C M A J$

DOI:Io.I503/cmaj.080I54

\section{Securing Canada's isotope supply}

The isotope shortage scare caused by the Chalk River reactor's shutdown has prompted Europe to call for a global coordination policy and could spur the creation of a United States supplier, but what does it all mean for Canada?

One thing is certain: Canadian doctors believe this country's nuclear medicine landscape is overdue for wholesale change. "The status quo is totally unacceptable," says Dr. Jean-Luc Urbain, president of the Canadian Society of Nuclear Medicine.

In the short term, Urbain says, Canada must create a backup plan in case the Chalk River reactor is again shutdown unexpectedly. Since there are few other options now available, that would mean improving coordination with foreign suppliers, though he believes they have nowhere near the capacity to keep Canada fully stocked in isotopes.

The most important task that must be accomplished to secure Canada's isotope supply falls to Atomic Energy of Canada Ltd. - getting the 2 MAPLE (Multipurpose Applied Physics Lattice Experiment) reactors working as soon as possible. "Having I reactor and no backup source in Canada is extremely dicey," Urbain says.

Ultimately, even the commissioning of the new reactors might not be enough to fully ensure the national isotope supply will never again be in jeopardy. In the unlikely event the entire Chalk River site met with catastrophe - "a pseudoChernobyl," as Urbain put it - Canada would be left without a domestic supplier. "In that worst possible scenario, you definitely want to have isotope production somewhere else. It would make sense to activate a reactor in the United States."

Because isotopes decay rapidly (molybdenum-99 has a half-life of 66 hours), it's not difficult to see the logic in having a back-up supplier across a border rather than over an ocean. But the creation of a United States supplier, which many say is inevitable, will not be applauded by all nuclear medicine stakeholders - MDS Nordion and Atomic Energy of Canada Ltd. stand to lose millions.

"We can't really use the argument that Canada's nuclear industry will suffer if the rest of the world becomes less dependent on I supplier that has definitely shown its weakness. ... Isn't the worldwide health of citizens more important than the commercial interests of $\mathrm{I}$ or 2 Canadian companies?” 